\title{
Parasitism in Kansas in the 1800s - A glimpse to the past through the analysis of grave sediments from Meadowlark cemetery
}

\author{
Matthieu Le Bailly $/^{+}$, Marcelo LC Gonçalves*, Christine Lefèvre**, Donna C Roper***, \\ Jeremy W Pye***, Adauto Araujo*, Françoise Bouchet
}

\begin{abstract}
Université de Reims, UFR de Pharmacie, EA 3798, Laboratoire de Paléoparasitologie, CNRS UMR 5197, 51, rue Cognacq-Jay, 51096 Reims cedex, France *Escola Nacional de Saúde Pública-Fiocruz, Rio de Janeiro, RJ, Brazil **Muséum National d'Histoire Naturelle, Paris cedex 05, France ***Department of Sociology/Anthropology/Social Work, Kansas State University, Manhattan, KA, US ****Department of Anthropology, University of Arkansas, Fayetteville, AK, US
\end{abstract}

During the excavations of the XIX century Meadowlark cemetery (Manhattan, Kansas, US), samples of sediments were taken from around five skeletons, and analyzed to detect intestinal parasites. No helminth eggs were found, but immunological ELISA tests for Entamoeba histolytica were positive in three samples. The immunological techniques have been successfully used in paleoparasitology to detect protozoan infections. Amoebiasis could have been a severe disease in the past, especially where poor sanitary conditions prevailed, and there is evidence that this cemetery may have been used in a situation where poor sanitary conditions may have prevailed. The presence of this protozoan in US during the late XIX century gives information on the health of the population and provides additional data on the parasite's evolution since its appearance in the New World.

Key words: paleoparasitology - ancient diseases - paleoepidemiology - protozoal infection - amoebiasis

Scientists have been using different techniques to look for parasites in ancient material (Reinhard et al. 1987, Araujo et al. 1998, Bouchet et al. 2003a). Coprolites or desiccated feces, or fecal remains mixed with soil sediment are commonly found in archaeological excavations. The parasitological analysis of such material yields rich information about paleopathologies, human migrations, cultural changes, dietary habits, paleoclimates, parasite dispersion, and host migrations throughout space and time (Reinhard et al 2001, Bouchet et al. 2003b, Gonçalves et al. 2003).

\section{MATERIALS AND METHODS}

The analyzed sediments were collected during the excavation of the Meadowlark Cemetery, on the grounds of Meadowlark Hills Retirement Community in Manhattan, Kansas. This cemetery was used during the period ca. 1860 to 1900 . It was excavated during the summer and early fall of 2004 to make way for construction of new residences on the retirement community property. A total of 17 graves were revealed. Thirteen of these graves contained skeletons. Sediment samples from the abdominal region of five skeletons were studied: MC F9, F10, F12, F13, and F17 (Table).

The material was submitted to the standard paleoparasitological examination using an optical microscope to

Financial support: CNRS; Capes/Cofecub, CNPq, TechLab ${ }^{\circledR}$, Fumouze, Millipore ${ }^{\circledR}$

${ }^{+}$Corresponding author: matthieu.lebailly@univ-reims.fr

Received 20 July 2006

Accepted 16 October 2006 search for helminth eggs. A commercially available enzyme-linked immunosorbent assay (ELISA) with monoclonal antibodies was used to test for antigen from Entamoeba histolytica (Haque et al. 1995, 2000) and Giardia duodenalis (Aldeen et al. 1998, Boone et al. 1999), two common intestinal protozoan parasites.

For the standard paleoparasitological examination, the samples were rehydrated for a week in $0.5 \%$ trisodic phosphate and 5\% glycerinated solution. The material was then crushed in a mortar. The suspension was submitted to an ultrasound device for $1 \mathrm{~min}$ at $50^{\circ} \mathrm{C}$, on a frequency of 35 $\mathrm{kHz}$, and the suspension strained through $315-\mu \mathrm{m}, 160$ $\mu \mathrm{m}, 50-\mu \mathrm{m}$, and $25-\mu \mathrm{m}$ meshes. A portion of each sample was used for microscopic examination. The material was placed on a slide that was covered with a coverslip and examined for evidence of parasites and food remains. Twenty slides of each sample were examined at magnification of $\times 100$ and $\times 400$ (Bouchet et al. 2001).

For the ELISA tests, the E. histolytica II and the Giardia II assay (TechLab, Blackburg, VA, US) were used. Sample preparation was quite different to provide physicochemical parameter modifications, especially due to formalin (Hould 1984, Exbrayat 2000). The samples were rehydrated for one week in ultra-pure water obtained from a purification system manufactured by Millipore ${ }^{\circledR}$ (Direct$\left.Q^{T M} 5\right)$. Samples were preserved in the freezer $\left(2-4^{\circ} \mathrm{C}\right)$ during the rehydration phase to avoid bacteria and fungi development. Manufacturer's directions were followed and results were interpreted by visual inspection and using a spectrophotometer. A test sample was considered positive if it had an obvious yellow color when compared to the negative control well. A test sample was considered negative if it was colorless or less yellow than the negative control well. The absorbance of each specimen was also measured at $450 \mathrm{~nm}$ wavelength (Haque et al. 2000). 


\section{RESULTS}

Microscopic examination revealed no helminth eggs resulting from an infestation of any one of the various parasitic worm species (including roundworm and hookworm) in any of the five analyzed samples. Samples MC F10, F12, and F13 were positive for the presence of the $E$. histolytica antigen, the causal agent of amoebic dysentery and amoebic liver abscess (Table). All samples were negative for the $G$. duodenalis antigen.

Parasites are biological markers that can be used to track ancient host migrations (Araújo et al. 2003). The finding of parasite remains in archaeological material is a tool to trace the evolution of past infections worldwide. Well-preserved parasite eggs or protozoan antigen recovered by immunoassays techniques are now beginning to reveal the origin and evolution of infectious diseases in the past (Bouchet et al. 2002, Le Bailly et al. 2003a, Ortega \& Bonavia 2003)

\section{DISCUSSION}

The former species E. histolytica was separated in 1993 into two species, E. dispar, a non-pathogenic intestinal parasite and E. histolytica, which can cause dysentery and extra-intestinal diseases in humans (Diamond \& Clark 1993). Although microscopy cannot differentiate between them, isoenzyme analysis and specific molecular techniques are able to distinguish $E$. histolytica from $E$. dispar (Haque et al. 1998, Huston et al. 1999).

$E$. histolytica had previously been found in archaeological material using the immunoassay technique (Gonçalves et al. 2004) on samples from other sites. The older traces were found in samples from Switzerland dated from around 5300 years BP (Gonçalves et al. 2004). Although protozoan cysts are not as resistant to decay as are helminth eggs, cyst antigens can remain stable for several centuries. Immunoassays using monoclonal antibodies to detect such antigens are very specific and are a reliable tool in paleoparasitology (Gonçalves et al. 2002, 2004). Amoebiasis is a parasitic disease related to contamination of drinking water and food polluted with feces, reflecting poor sanitation conditions wherever it is found.

It is possible to infer sanitation conditions and even lifestyle in ancient human settlements through the recovery and identification of parasites in archaeological material (Reinhard 1992, Araujo et al. 1998, Le Bailly et al. 2003a). Paleoparasitological studies in Neolithic settlements (Bouchet 1997, Bouchet et al. 1997, Le Bailly et al. 2003b, 2005), ancient Roman fortifications, and medieval villages
(Bouchet et al. 2000) have revealed a picture of the intensive relationship between parasites and humans in the Old World.

Although many intestinal parasites infected New World populations before contact, after colonization, these parasitoses seem to have become a major public health problem. As already noted, parasites are common where humans live in poor sanitary conditions. The parasitic agents most commonly are transmitted through contaminated food or water sources, as well as poor waste management and education about proper cleanliness. Due to the factors of transmission listed above, often individuals of low socio-economic status fall prey to such parasites. This was particularly the case in the XIX century.

Health and evidence of stress are largely a reflection of quality of life, and therefore are strongly related to socio-economic status. While there are degrees of environmental factors involved in the assessment of quality of life, such as pathological stressors, they are often tied into culturally created factors such as sanitation, access to resources, and education (Goodman et al. 1988). Thus, the identification of particular markers, which can elucidate the relationship between status and quality of life, such as the analysis of parasites, are important (Larsen 1997).

At the outset of the excavations of Meadowlark Cemetery, the researchers learned that William H Stillman had owned the land on which the cemetery was formed. A local informant, whose family lived on the property since 1915, claimed that Stillman was running the county poor farm and an orphanage in the late XIX century (Pye et al. 2004). A Manhattan brochure printed in 1888 AD states that an orphan home was arranging to relocate to Manhattan, however, no concrete evidence of this occurring has been found (Board of Trade - Manhattan, Kansas 1888). If an orphanage existed on this property during the use life of the cemetery, then one would expect to see a large proportion of subadults present, as well as a high incidence of infection due to low bacterial and parasitic thresholds. In fact, the largest number of burials was those of subadults.

Six burials were those of adults, four of them young adult males, one an elderly male, and one an adult female. This is consistent with a possibility put forth before the excavation began that this cemetery was used for burial of residents of a poor farm. Poor farms at this time in the US were established to provide care and work for the indigent and a means of subsistence for young laborers, often at the lowest possible cost to the federal or town gov-

TABLE

Characteristics of grave features and burials at the Meadowlark Cemetery, and positivity for Entamoeba histolytica ELISA test

\begin{tabular}{lllll}
\hline Burials & Age & Sex & Coffin/Grave length & E. histolytica antigen \\
\hline Feature 9 & Subadult $<1 \mathrm{yr}$ & Undetermined & $107.82 \mathrm{~cm} / 139.12 \mathrm{~cm}$ & Negative \\
Feature 10 & Subadult & Undetermined & $154 \mathrm{~cm} / 134.65 \mathrm{~cm}$ & Positive \\
Feature 12 & Subadult & Undetermined & $141.66 \mathrm{~cm}$ & Positive \\
Feature 13 & Adult $18-25 \mathrm{yrs}$ & Male & $211.12 \mathrm{~cm}$ & Positive \\
Feature 17 & Subadult & Undetermined & $100.69 \mathrm{~cm} / 122.58 \mathrm{~cm}$ & Negative \\
\hline
\end{tabular}


ernment (Bell 1990). There is some evidence that Stillman may have been receiving money from the county for care of the poor (Manhattan Enterprise, 8/13/1880), although there are no specific records that he ran a poor farm. By definition, orphans and poor migrant workers would not usually be able to attain high social status in the society, and therefore might also have been exposed to high levels of parasitic agents.

\section{Conclusion}

The finding of E. histolytica in organic sediment from the Meadowlark Cemetery reflects a crowed area and poor sanitation conditions in this particular Kansas community in the late XIX century. G. duodenalis was not found in the material. Since G. duodenalis is commonly found in ecosystems similar to those where E. histolytica is usually found, this could reflect a true absence of $G$. duodenalis or be a false negative result. However, caution should be exerted in the interpretation of negative results in ancient samples, as antigen structure may be compromised in the uncontrolled preservation conditions. In any event, the results obtained during the study of the Meadowlark Cemetery sediment samples should encourage others to use various immunological techniques, or immunological and molecular techniques together. Such techniques might include immunofluorescence or polymerase chain reaction-solution hybridation enzyme-linked immunoassay (Aguirre et al. 1995, 1997) that could be more sensitive for studying the evolution of the parasites genome.

\section{REFERENCES}

Aguirre A, Molina S, Blotkamp C, Verveij J, Vinuesa T, Valls ME, Guhl F, Polderman A, Jimenez de Anta MT, Corachan M, Gonzalez-Ruiz A, Frame IA, Warhurst D 1997. Diagnosis of Entamoeba histolytica and Entamoeba dispar in clinical specimens by PCR-SHELA. Arch Med Res 28: 282284.

Aguirre A, Warhurst DC, Guhl F, Frame IA 1995. Polymerase chain reaction-solution hybridization enzyme-linked immunoassay (PCR-SHELA) for the differential diagnosis of pathogenic and non-pathogenic Entamoeba histolytica. Trans R Soc Trop Med Hyg 89: 187-188.

Aldeen WE, Carroll K, Robinson A, Morrison M, Hale D 1998. Comparison of nine commercially available enzyme-linked immunosorbent assays for detection of Giardia lamblia in fecal specimens. J Clin Microbiol 36: 1338-1340.

Araújo A, Reinhard K, Bastos OM, Costa LC, Pirmez C, Iñiguez A, Vicente AC, Morel CM, Ferreira LF 1998. Paleoparasitology: perspectives with new techniques. Rev Inst Med Trop São Paulo 40: 371-376.

Bell EL 1990. The historical archaeology of mortuary behavior: coffin hardware from Uxbridge, Massachusetts. Hist Archaeol 24: 54-78.

Board of Trade, Manhattan, Kansas 1888. Manhattan, Riley County, Kansas - Kansas (Manhattan Brochure/Map), Kansas State University Libraries, Special Collections, Manhattan, Kansas.

Boone JH, Wilkins TD, Nash TE, Brandon JE, Macias EA, Jerris RC, Lyerly DM 1999. TechLab and alexon Giardia enzyme- linked immunosorbent assay kits detect cyst wall protein $1 . J$ Clin Microbiol 37: 611-614.

Bouchet F 1997. Intestinal capillariasis in neolithic inhabitants of Chalain (Jura, France). Lancet 349 (9047): 256.

Bouchet F, Bentrad S, Dommelier S, Paicheler JC, Pétrequin P 1997. Capillarioses intestinales: nématodoses du Néolithique. Bull Soc Fr Parasitol 15: 49-54.

Bouchet F, Harter S, Paicheler JC, Araujo A, Ferreira LF 2002. First recovery of Schistosoma mansoni eggs from a latrine in Europe (15-16th centuries). J Parasitol 88: 404-405.

Bouchet F, Harter S, Le Bailly M 2003a. The state of the art of paleoparasitological research in the Old World. Mem Inst Oswaldo Cruz 98 (Suppl. 1): 95-101.

Bouchet F, Guidon N, Dittmar K, Harter S, Ferreira LF, Chaves SM, Reinhard K, Araújo A 2003b. Parasites remains in archaeological sites. Mem Inst Oswaldo Cruz 98 (Suppl. 1): 47-52.

Bouchet F, West D, Lefèvre C, Corbett D 2001. Identification of parasitoses in child burial from Adak Island (Central Aleutian Islands, Alaska). CR Acad Sc Paris (série III) 324: 123-127.

Diamond LS, Clark CG 1993. A redescription of Entamoeba histolytica Shaudinn, 1903 (amended Walker, 1911) separating it from Entamoeba dispar Brumpt, 1925. J Eukariot Microbiol 40: 340-344.

Exbrayat JM 2000. Méthodes Classiques de Visualisation du Génome en Microscopie Photonique, Tec et Doc, Paris.

Gonçalves MLC, Araujo A, Duarte R, Pereira da Silva J, Reinhard K, Bouchet F, Ferreira LF 2002. Detection of Giardia duodenalis antigen in coprolites using a commercially available enzyme-linked immunosorbent assay. Trans $R$ Soc Trop Med Hyg 96: 640-643.

Gonçalves MLC, Araujo A., Ferreira LF 2003. Human intestinal parasites in the past: new findings and a review. Mem Inst Oswaldo Cruz 98 (Suppl. 1): 103-118.

Gonçalves M, Silva V, Andrade C, Rocha G, Le Bailly M, Bouchet F, Ferreira LF, Araujo A 2004. Amebiasis distribution in the past: first steps in using an immunoassay technique. Trans $R$ Soc Trop Med Hyg 98: 88-91.

Goodman AH, Thomas RB, Swedlund AC, Armelagos GJ 1988. Biocultural Perspectives on Stress in Prehistoric, Historical, and Contemporary Population Research. Yearb Phys Anthropol 21: 169-202.

Haque R, Ali IKM, Akther S, Petri Jr WA 1998. Comparison of PCR, isoenzyme analysis, and antigen detection for diagnosis of Entamoeba histolytica infection. J Clin Microbiol 36: 449-452.

Haque R, Mollah NU, Ali KM, Alam K, Eubanks A, Lyerly D, Petri Jr WA 2000. Diagnosis of amebic liver abscess and intestinal infection with the TechLab Entamoeba histolytica. II antigen detection and antibody tests. J Clin Microbiol 38 : 3235-3239.

Haque R, Neville LM, Hahn P, Petri WA 1995. Rapid diagnosis of Entamoeba infection by using Entamoeba and Entamoeba histolytica stool antigen detection kits. J Clin Microbiol 33: 2558-2561.

Hould R 1984. Techniques d'Histopathologie et de Cytopathologie, Maloine, Paris. 
Huston CD, Haque R, Petri Jr WA 1999. Molecular-based diagnosis of Entamoeba histolytica infection. Expert Rev Mol Med 22: 1-11.

Larsen CS 1997. Bioarchaeology: Interpreting Behavior from the Human Skeleton, Cambridge Studies in Biological Anthropology 21, Cambridge University Press, Cambridge.

Le Bailly M, Harter S, Bouchet F 2003a. A l'interface de la biologie et de l'archéologie: la paléoparasitologie. Archéopages 11: $12-17$.

Le Bailly M, Leuzinger U, Bouchet F 2003b. Dioctophymidae eggs from coprolites from neolithic site of Arbon-Bleiche 3 (Switzerland). J Parasitol 89: 1073-1076.

Le Bailly M, Leuzinger U, Schlichtherle H, Bouchet F 2005. Diphyllobothrium: neolithic parasite? J Parasitol 91: 957959.
Manhattan Enterprise 1880. Issue of Manhattan Enterprise, August 13, 1880, Kansas State Historical Society, Manhat$\tan$.

Ortega YR, Bonavia D 2003. Cryptosporidium, Giardia, and Cyclospora in ancient Peruvians. J Parasitol 89: 635-636.

Pye JW, Smith HC, Roper DC 2004. Excavations at Meadowlark Cemetery, Manhattan. Curr Archaeol Kansas 5: 7792.

Reinhard KJ 1992. Parasitology as an interpretive tool in archaeology. Am Antiquity 57: 231-245.

Reinhard KJ, Araújo A, Ferreira LF, Coimbra JR CE 2001. American hookworm antiquity. Med Anthropol 20: 97-101.

Reinhard KJ, Hevly RH, Anderson GA 1987. Helminth remains from prehistoric Indian Coprolites from the Colorado Plateau. J Parasitol 70: 630-639. 